\title{
HYDRAULIC CHARACTERISTICS AND PERFORMANCE EVALUATION OF MODERN IRRIGATION SYSTEMS
}

\author{
Morad, M. M. ${ }^{1}$ and S. I. A. Abdel-Aal ${ }^{2}$
}

\begin{abstract}
The hydraulic characteristics of three irrigation systems (trickle, subsurface and sprinkler irrigation) were investigated in terms of required pressure and flow characteristics of emitters, leaky pipes and sprinklers. Added to that, the pump power required for operating the used irrigation systems was also estimated. The performances of the used irrigation systems in terms of application efficiency, coefficient of uniformity, flow rate variation and irrigation system efficiency were experimentally determined under conditions of sandy soil.
\end{abstract}

The experimental results reveal the following:

- The required pump pressure to operate the trickle, subsurface and sprinkler irrigation systems must not be less than 2.9, 2.9 and 4.3 bar, so as to pump water from the emitters, lucky pipe and sprinkler at pressure of 1.3, 1.3 and 2.4 bar.

- The required pump power to operate the trickle, subsurface and sprinkler irrigation systems must be not more than $32.6 \mathrm{~kW}$ instead of the already used pump in the experimented area $(44.1 \mathrm{~kW})$ that will be saved power with percentage of $26 \%$.

- The exponent $x$ value of emitters was 0.77 meaning that the flow rate through emitters is between a laminar and turbulent.

- Values of application efficiency and emission uniformity for subsurface irrigation system were much higher than trickle irrigation system.

- Sprinkler irrigation system recorded higher flow rate variation comparing with trickle and subsurface irrigation systems.

Keywords: irrigation systems, hydraulic characteristics, friction losses, pump, efficiency, uniformity, operating pressure.

\footnotetext{
${ }^{1}$ Prof. of Agric. Eng. Dept. Fac. of Agric., Zagazig Un.

${ }^{2}$ Assoc. Prof. of Agric. Dept. Eng., Fac. of Agric., Zagazig Un.
} 


\section{INTRODUCTION}

A detailed hydraulic analysis of irrigation systems is very important for design and evaluation purposes. In the present 1 irrigation market there is a variety of irrigation systems accessible to the grower. The typical as opposed to the potential performance of these systems and the respective management criteria, under local conditions, can be major factors in the choice of one system over the other. Irrigation systems are selected, designed and operated to supply the irrigation requirements of each crop on the farm while controlling deep percolation, runoff, evaporation, and operational losses, to establish a sustainable production process.

Hydraulic design and proprieties of irrigation system are mainly dependent on flow rate, flow path, operating pressure, in addition to water properties. In order to reach a general solution for hydraulic design of irrigation system, fluid and flow should be investigated.

Burt et al., (1997) stated that the distribution uniformity of different types of irrigation will be influenced by different factors that are characteristic of the particular system. Irrigation is influenced by the condition of sprinkler packages and the pressure variation within the system.

Griffiths and Lecler (2001) evaluated the irrigation systems (sprinkler and subsurface) performance and found that coefficient of uniformity and distribution uniformity range from 66 to $84 \%$ and from 59 to $78 \%$ under sprinkler irrigation, while under subsurface irrigation distribution and coefficient of uniformity values range from 33 to $94 \%$ and from 53 to $98 \%$.

Shawky et al. (2001) found that the application efficiency values were $92.9,92.56,81.48$ and $65.7 \%$ for subsurface drip, surface drip, sprinkler and furrow systems, respectively.

Abdel-Aziz (2003) found that the average application efficiency and distribution uniformity under drip irrigation system increased by 5.6, 18 and $41 \%$ and $3.45,8.04$ and $20 \%$ compared to bubbler, gated pipes and traditional irrigation systems, respectively.

Safi et al. (2007) obtained coefficient of uniformity values of 96.9 and $91.8 \%$ for subsurface and surface drip irrigation systems respectively. 
Appropriate design for irrigation system had to be managed for successful operation under different conditions.

So, the objectives of this research are to:-

- Investigate the hydraulic characteristics of three different irrigation systems (trickle, subsurface and sprinkler irrigation).

- Determine the efficiencies of the used irrigation systems (application efficiency, coefficient of uniformity, emission uniformity, flow rate variation and irrigation system efficiency.

\section{MATERIALS AND METHODS}

Field experiments were carried out in open field conditions at Wadi EL Natrown (وادي النطرون) on Farm Irrigation Department Research Station, Water Management and Irrigation Systems Research Institute, El-Bohera Governorate (محافظة البحيرة). Some soil physical and chemical properties of the experimental plots were determined as shown in Table (1).

Table (1): Some physical and chemical analyses of the experimental field.

\begin{tabular}{|c|c|c|c|c|c|c|c|c|c|c|}
\hline \multirow{2}{*}{ 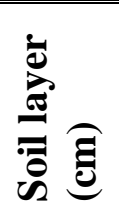 } & \multicolumn{3}{|c|}{$\begin{array}{c}\text { Particle size } \\
\text { distribution \% }\end{array}$} & \multirow{2}{*}{ 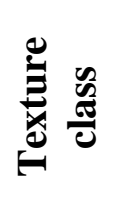 } & \multirow{2}{*}{ 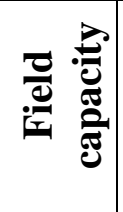 } & \multirow{2}{*}{ 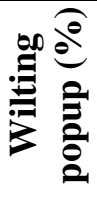 } & \multirow{2}{*}{ 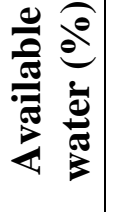 } & \multirow{2}{*}{ 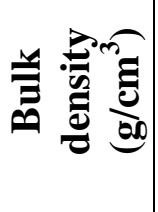 } & \multirow{2}{*}{ v } & \multirow{2}{*}{$\frac{\pi}{2}$} \\
\hline & Sand & Silt & Clay & & & & & & & \\
\hline $0-20$ & 9 & 3. & & \multirow{3}{*}{ Sandy } & 5 & 5.5 & 7.75 & 1.65 & 1.45 & 8.2 \\
\hline $20-40$ & 95.0 & 3.3 & 1. & & 14.25 & 4.9 & 9.35 & 1.5 & 1.55 & 8.11 \\
\hline $40-60$ & 95.7 & 3.0 & 1.3 & & 14.50 & 4.3 & 10.2 & 1.44 & 1.65 & 7.97 \\
\hline
\end{tabular}

Performance evaluation and efficiencies were conducted in an experimental area reached 771, 771 and $2592 \mathrm{~m}^{2}$ for trickle, subsurface and sprinkler irrigation systems.

The irrigation water was obtained from local well. The irrigation water has a $\mathrm{pH}$ of 7.14 , total soluble salts of $755 \mathrm{ppm}$ and sodium adsorption ratio value of 12.1 .

\section{1- Materials}

Three irrigation systems (trickle, subsurface and sprinkler) were installed in the experimental area. The three irrigation systems contain the following general components: 
- Pump: An electrical centrifugal pump was used with $44.1 \mathrm{~kW}$ engine power and a discharge of $100 \mathrm{~m}^{3} / \mathrm{h}$ at 4 bar operating pressure.

- Control head consisted of (centrifugal pump, pressure regulator, pressure gauges, flow meter and filters).

- Pipe network consisting of main, sub-main lines, secondary lines and manifold (160 mm diameter PVC were used for main line, between 90 and $110 \mathrm{~mm}$ PVC for sub-main line, between 63-75 $\mathrm{mm}$ for secondary lines and between $63-50 \mathrm{~mm}$ for manifold line).

- Trickle irrigation system had GR lateral lines that are made of polyethylene pipes with $16 \mathrm{~mm}$ diameters, $25 \mathrm{~cm}$ emitter distance, $3.51 / \mathrm{h}$ emitter discharge at 1.30 bar operating pressure and $60 \mathrm{~cm}$ between laterals.

- Subsurface irrigation system had lateral with leaky pipe porous flexible rubber hose of $16 \mathrm{~mm}$ diameter with flow rate of $3.55 \mathrm{lph} / \mathrm{m}$ at 1.3 bar operating pressure, $100 \mathrm{~cm}$ distance between leaky pipes laterals and installed at $20 \mathrm{~cm}$ under the soil surface.

- Sprinkler irrigation system had lateral lines that are made of PVC pipes with $50 \mathrm{~mm}$ diameter, $12 \mathrm{~m}$ sprinkler distance, $12 \mathrm{~m}$ distance between sprinkler laterals, sprinkler riser $19 \mathrm{~mm}$ diameter, $1.25 \mathrm{~m}$ high, rotating sprinklers $1.9 \mathrm{~mm}$ outer diameter and $2.2 \mathrm{~m}^{3} / \mathrm{h}$ discharge under operating pressure of 2.4 bar.

Fig. (1) shows the layout components of trickle, subsurface and sprinkler irrigation system.

\section{2- Methods}

\subsection{Hydraulic charaecterstics of the used irrigation systems.}

\subsubsection{Determination of the required operating pressure.}

It is of great importance to adjust the operating pump pressure required to move the water through the irrigation system network so as to obtain suitable pressure at the inlet of the lateral lines.

In this case Bernoulli's equation is applied

$$
E_{P}=E_{L}+h_{L P \rightarrow L}
$$

Where:

$\mathbf{E}_{\mathbf{P}}=$ total energy at the pump outlet.

$\mathbf{E}_{\mathbf{L}}=$ total energy at the lateral line inlet.

$\mathbf{h}_{\mathbf{L} \mathbf{P} \rightarrow \mathbf{L}}=$ total energy losses between pump outlet and lateral line inlet. 


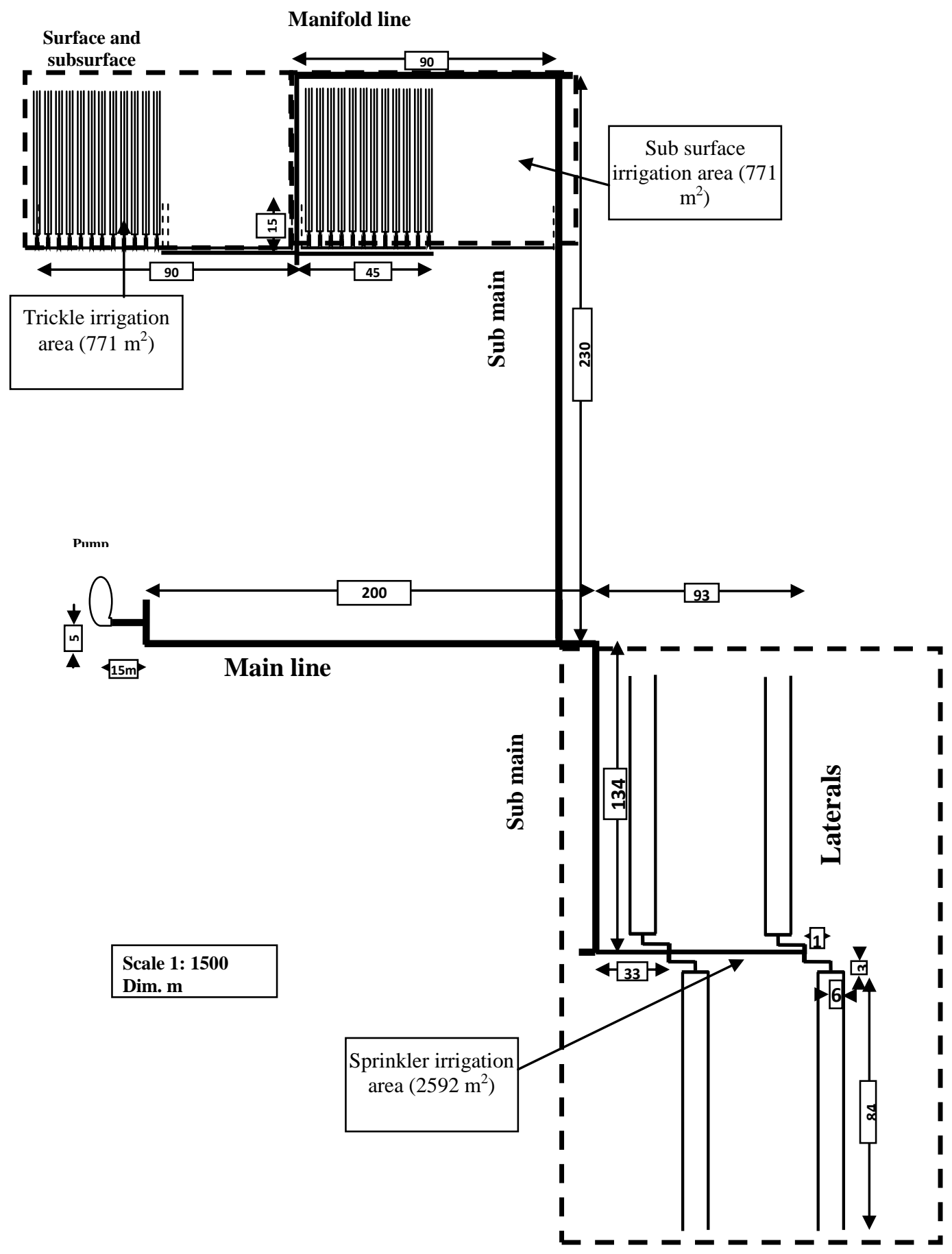

Fig. (1): Trickle, subsurface and sprinkler irrigations layout. 
Bernoulli's equation can be also written in the following form:

$$
Z_{p}+\frac{v_{p}^{2}}{2 g}+\frac{P_{p}}{w}=Z_{L}+\frac{v_{L}{ }^{2}}{2 g}+\frac{P_{L}}{w}+h_{L P \rightarrow L}
$$

Where:

$\mathrm{Z}_{\mathrm{P}}, \mathrm{Z}_{\mathrm{L}}=$ potential heads at the pump outlet and the lateral line inlet, $\mathrm{m}$;

$\mathrm{v}_{\mathrm{P}}^{2}, \mathrm{v}_{\mathrm{L}}^{2}=$ kinetic heads at the pump outlet and the lateral line inlet, $\mathrm{m}$.

$\frac{P_{p}}{w}, \frac{P_{L}}{w}=$ pressure heads at the pump outlet and the lateral line inlet,

$\mathrm{m}$.

If the required pressure at the lateral line inlet is 1.3 bar for both drip and subsurface irrigation systems and 2.4 bar for sprinkler irrigation system (more than the atmospheric pressure). So, the required pump pressure can be determined using the previously mentioned Bernoulli's equation only, if the total head losses $\left(h_{\mathrm{L} P \rightarrow \mathrm{L}}\right)$ is obtained. The total head losses can be expressed as follows:

$$
\mathbf{h}_{\mathbf{L} P \rightarrow \mathbf{L}}=\mathbf{h}_{\mathbf{f} \rightarrow \mathbf{L}}+\mathbf{h}_{\mathbf{S} P \rightarrow \mathbf{L}}
$$

Where:

$\mathbf{h}_{\mathbf{f} \mathbf{P} \rightarrow \mathbf{L}}=$ friction losses between pump outlet and lateral line inlet;

$\mathbf{h}_{\mathbf{s} \mathbf{P} \rightarrow \mathbf{L}}=$ secondary losses between pump outlet and lateral line inlet.

\section{- Determination of friction losses}

To determine the friction losses in the network (Hazen-Williams, 1920) equation is used:

$$
h_{f}=\frac{1.22 \times 10^{10} \times L}{D^{4.78}}\left(\frac{Q}{C}\right)^{1.852}
$$

Where:

$\mathrm{h}_{\mathrm{f}}=$ friction head losses, $\mathrm{m}$;

$\mathrm{L}=$ length of pipe, $\mathrm{m}$;

$\mathrm{D}=$ inside diameter of the pipe, $\mathrm{mm}$;

$\mathrm{Q}=$ discharge, $1 / \mathrm{sec}$;

$\mathrm{C}=$ Hazen-Williams coefficient.

The Hazen-Williams coefficient value for the used PVC and PE pipes in the irrigation systems network was 150 .

\section{- Determination of secondary losses}

To determine the secondary losses in the network (valves and links). The 
following equation is used:

$$
h s=K \times\left(\frac{v^{2}}{2 g}\right)
$$

Where:

$\mathrm{h}_{\mathrm{s}}=$ secondary head losses, $\mathrm{m}$;

$\mathrm{v}=$ velocity, $\mathrm{m} / \mathrm{sec}$;

$\mathrm{g}=$ acceleration due to gravity, $\mathrm{m} / \mathrm{sec}^{2}$;

$\mathrm{K}=$ coefficient factor.

\subsubsection{Determination of the required pump power.}

The power imparted to the water by the pump is called water power. To calculate water power, the flow rate and the pump head must be known. The following equation is used:

$$
W H P=\frac{W \times Q \times H_{m}}{75}
$$

The engine power required for operating the pump is calculated using the following equation:

$$
B H P=\frac{W \times Q \times H_{m}}{\eta_{m} \times 75}
$$

Where:

$$
\begin{aligned}
& W H P=\text { water power, } \mathrm{hp} ; \\
& B H P=\text { engine brake horse power, } \mathrm{hp} ; \\
& \mathrm{W}=\text { density of fluid, } \mathrm{kg} / \mathrm{m}^{3} ; \\
& \eta_{m}=\text { pump efficiency and } \\
& \mathrm{H}_{\mathrm{m}}=\text { pump head, } \mathrm{m} ; \\
& \quad H_{m=} H_{m s} H_{m d}
\end{aligned}
$$

Where:

$$
\begin{aligned}
& H_{m s}=\text { drawdown, m; } \\
& H_{m d}=\mathbf{h}_{\mathbf{L} \mathbf{P} \rightarrow \mathbf{L}}
\end{aligned}
$$

Over head must be added to the engine power as follows:

$$
\text { Required pump power }=1.1 \times \mathrm{BHP}
$$

\subsubsection{Flow characteristics of emitters, leaky pipes and sprinklers.}

The discharge $(\mathrm{Q})$ of the emitter, $1 \mathrm{~m}$ leaky pipe and sprinkler $(\mathrm{l} / \mathrm{h})$ was determined by collecting the water volume $(V)$ after time $(T)$ and applying the following equation: 


$$
Q=\frac{V}{T} \quad(1 / \mathrm{h})
$$

The flow characteristics of emitters can be characterized by the power curve equation. It was determined by (Keller and Karmel, 1975) that the following equation gives the relation between discharge and head of the dipper:

$$
q=k_{d} H^{x}
$$

Where:

$\mathrm{q}=$ emitter discharge, $1 / \mathrm{h} ;$

$k_{d}=$ specific coefficient of each emitter;

$\mathrm{H}=$ the pressure head of water at which the emitter is operated, $\mathrm{m}$;

$\mathrm{X}=$ is an exponent, which depends on the flow regime.

\subsection{Efficiencies of the used irrigation systems}

\subsubsection{Application efficiency}

Application efficiency (AE) is the ratio of the average depth of the irrigation water stored in the root zone (target) to the average depth of irrigation water applied, expressed as percent ( $\boldsymbol{W u}$ and Gitilin, 1975)

$$
\mathrm{AE}=\frac{\mathrm{W}_{\mathrm{DZ}}}{\mathrm{D}_{\mathrm{T}}} \times 100
$$

Where:

$\mathrm{W}_{\mathrm{DZ}}=$ depth of water stored in the root zone, $\mathrm{cm}$;

$\mathrm{D}_{\mathrm{T}} \quad=$ gross depth of applied water, $\mathrm{cm}$.

\subsubsection{Coefficient of uniformity}

A useful term for placing a numerical value on the uniformity of application for agricultural irrigation systems is coefficient of uniformity (CU). The CU was calculated from the following equation (Christiansen, 1942):

$$
C U=100 *\left[1-\frac{\sum|z-m|}{n m}\right]
$$

Where:

$\mathrm{Z}=$ individual depth of catch observations from uniformity tests, $\mathrm{mm}$;

$\mathrm{n}=$ number of observed cans;

$\mathrm{m}=$ mean depth of observations, $\mathrm{mm}$. 


\subsubsection{Flow rate variation.}

The flow rate variation $\left(\mathrm{q}_{\mathrm{var}}\right)$ is used to describe the uniformity of emitter, leaky pipe and sprinkler flow as caused by the hydraulic design and manufacturing variability. The flow rate variation was calculated from the following equation $(\mathbf{W u}, \mathbf{1 9 9 2})$ :

$$
q_{\mathrm{var}}=\left[\frac{q_{\max }-q_{\min }}{q_{\max }}\right] * 100
$$

Where:

$\mathrm{q}_{\max }=$ maximum flow rate, $1 / \mathrm{h}$;

$\mathrm{q}_{\min }=$ minimum flow rate, $1 / \mathrm{h}$.

\subsubsection{Emission uniformity.}

Emission uniformity (EU) of systems as a percentage was determined in the field by using EU test (Merriam and Keller, 1978) and calculated by using the following equation:

$$
E U=\frac{\mathrm{Q}_{\mathrm{n}}}{\mathrm{Q}_{\mathrm{a}}}
$$

Where:

$\mathrm{Q}_{\mathrm{n}}=$ average lowest discharge from low quarter, $1 / \mathrm{h}$;

$\mathrm{Q}_{\mathrm{a}}=$ average of all discharge, $1 / \mathrm{h}$.

\subsubsection{Irrigation system efficiency.}

Irrigation system efficiency (Es) was calculated from the following formula according to (Wu and Gitilin, 1975).

$$
\mathrm{Es}=\mathrm{AE} \times \mathrm{EU}
$$

\section{Results and Discussion}

\section{Hydraulic charaecterstics of the used irrigation systems.}

\subsection{The required pump pressure for operating the used irrigation} systems.

For operating the used irrigation systems pump must add energy to the water to overcome the losses occurred all over the pipes. In every irrigation system, there are some additional losses such as friction (due to various fittings) and secondary (other components of the system such as flow meters and intake strainers). Table (2) shows coefficient factor values for the used joints and valves in the irrigation systems network. 
Table (2): Coefficient factor of joints on links and valves.

\begin{tabular}{|c|c|}
\hline Types & K \\
\hline Elbow $90^{\circ}$ & 1 \\
\hline Elbow $45^{\circ}$ & 0.4 \\
\hline Tee in line & 0.35 \\
\hline Tee from line to branch & 1.2 \\
\hline Tee from branch to line & 0.8 \\
\hline Valve (depending on closure) & 0.7 \\
\hline Non return valve & 1.5 \\
\hline Saddle & 1.8 \\
\hline Reducer & 1 \\
\hline Water meter & 3 \\
\hline
\end{tabular}

Table (3) shows the friction and secondary losses under trickle and subsurface irrigation systems.

Table (3): Friction and secondary losses under trickle and subsurface irrigation systems.

\begin{tabular}{|c|c|c|c|c|c|c|c|c|c|c|}
\hline & \multicolumn{9}{|c|}{ Positions of friction and secondary losses } & \multirow{2}{*}{ Total } \\
\hline & $\mathbf{L}$ & 1 & 2 & 3 & 4 & 5 & 6 & 7 & $\mathbf{P}$ & \\
\hline $\mathbf{Q}$ & - & 12.5 & 25 & 50 & 50 & 100 & 100 & 100 & 100 & - \\
\hline $\mathbf{V}$ & - & 1.77 & 1.57 & 1.46 & 0.69 & 1.38 & 1.38 & 1.38 & 1.38 & - \\
\hline $\mathbf{h}_{\mathrm{s}}$ & - & 0.7 & 0.57 & 0.13 & 0.01 & 0.1 & 0.1 & 0.1 & 0.6 & 2.31 \\
\hline $\mathbf{h}_{\mathbf{f}}$ & - & 3.9 & 2 & 0.65 & 0.39 & 3.6 & 2.9 & 0.08 & 0.23 & 13.75 \\
\hline \multicolumn{10}{|c|}{ Total } & 16.06 \\
\hline
\end{tabular}

Figs. (2 and 3) show the details of losses components for trickle, subsurface and sprinkler irrigations.

Fig. (4) shows total energy line between pump outlet and laterals inlet. The total friction losses under trickle and subsurface irrigation systems were $13.75 \mathrm{~m}$, while the total secondary losses under the same systems were $2.31 \mathrm{~m}$. The operating pump pressure under trickle and subsurface irrigation systems was calculated using the modified Bernoulli's equation as follows: 


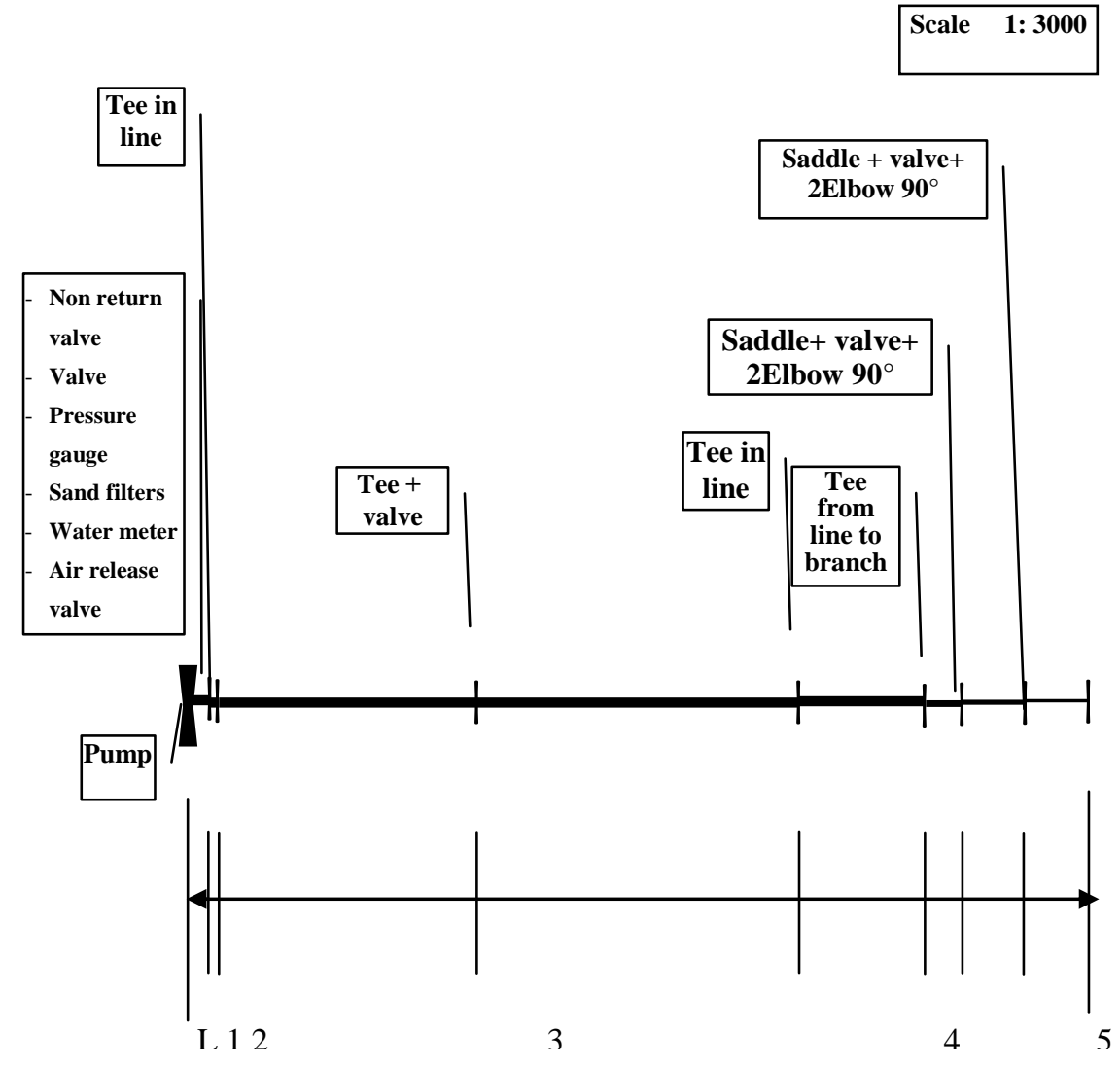

Positions of friction and secondary losses

Fig. (2): Details of losses components for trickle and subsurface irrigation system.

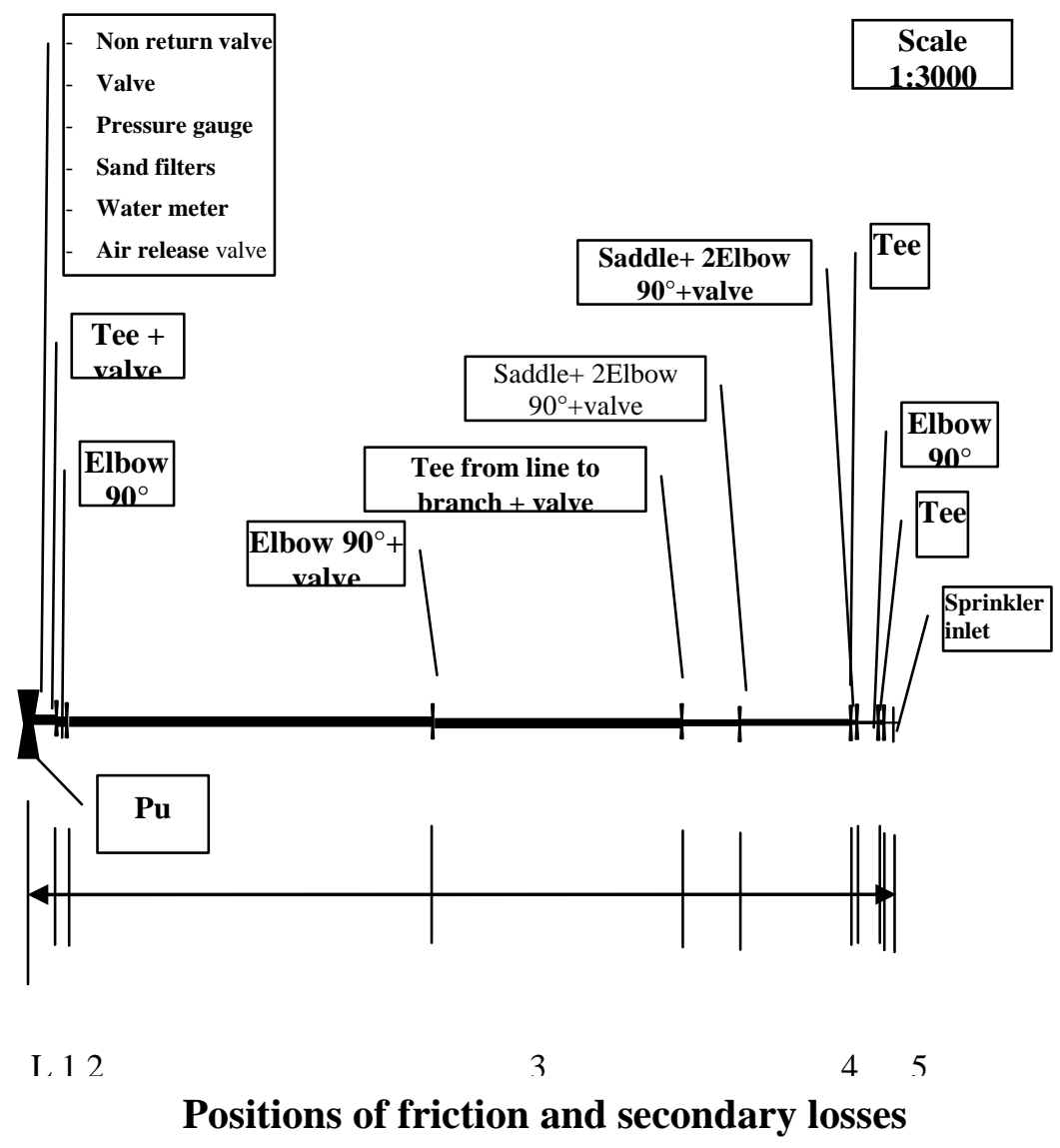

Fig. (3): Details of losses components for sprinkler irrigation systems. 


$$
Z_{p}+\frac{v_{p}^{2}}{2 g}+\frac{P_{p}}{w}=Z_{L}+\frac{v_{L}^{2}}{2 g}+\frac{P_{L}}{w}+h_{L P \rightarrow L}
$$

When: $\mathrm{Z}_{\mathrm{p}}=\mathrm{Z}_{\mathrm{L}}$

$$
\begin{gathered}
\frac{(1.38)^{2}}{2 \times 9.81}+\frac{P_{p}}{1}=\frac{(1.77)^{2}}{2 \times 9.81}+\frac{13}{1}+16.06 \\
\mathrm{P}_{\mathrm{p}}=29.1 \mathrm{~m}(2.9 \mathrm{bar}) .
\end{gathered}
$$

The friction and secondary losses under sprinkler irrigation system are as shown in Table (4).

Table (4): Friction and secondary losses under sprinkler irrigation system.

\begin{tabular}{|c|c|c|c|c|c|c|c|c|c|c|c|c|}
\hline & \multicolumn{10}{|c|}{ Positions of friction and secondary losses } & \\
\hline & $\mathbf{L}$ & $\mathbf{1}$ & $\mathbf{2}$ & $\mathbf{3}$ & $\mathbf{4}$ & $\mathbf{5}$ & $\mathbf{6}$ & $\mathbf{7}$ & $\mathbf{8}$ & $\mathbf{9}$ & $\mathbf{P}$ & Total \\
\hline $\mathbf{Q}$ & - & 12.5 & 25 & 25 & 50 & 100 & 100 & 100 & 100 & 100 & 100 & - \\
\hline $\mathbf{V}$ & - & 1.09 & 1.57 & 1.57 & 1.46 & 2.92 & 1.38 & 1.38 & 1.38 & 1.38 & 1.38 & - \\
\hline $\mathbf{h}_{\mathbf{s}}$ & - & 0.07 & 0.13 & 0.15 & 0.5 & 2 & 0.18 & 0.17 & 0.1 & 0.1 & 0.6 & 4 \\
\hline $\mathbf{h}_{\mathbf{f}}$ & - & 0.17 & 0.13 & 0.54 & 0.49 & 5.63 & 3.09 & 2.1 & 3.13 & 0.08 & 0.23 & 15.29 \\
\hline \multicolumn{11}{|c|}{ Total } \\
\hline
\end{tabular}

Fig. (5) shows total energy line between pump outlet and laterals inlet. The total friction and secondary losses on sprinkler irrigation system were 15.29 and $4 \mathrm{~m}$. The operating pump pressure under sprinkler irrigation system was calculated using the modified Bernoulli's equation as follows

$$
Z_{p}+\frac{v_{p}^{2}}{2 g}+\frac{P_{p}}{w}=Z_{L}+\frac{v_{L}^{2}}{2 g}+\frac{P_{L}}{w}+h_{L P \rightarrow L}
$$

When: $Z_{p}=Z_{L}$

$$
\begin{gathered}
\frac{(1.38)^{2}}{2 \times 9.81}+\frac{P_{p}}{1}=\frac{(1.09)^{2}}{2 \times 9.81}+\frac{24}{1}+19.29 \\
\mathrm{P}_{\mathrm{p}}=43.25 \mathrm{~m}(4.3 \text { bar }) .
\end{gathered}
$$

The previous analysis shows that the required pump pressures to operate the trickle and subsurface irrigation systems must be not less than 2.9 bar, so as to pump water from the emitters at pressure of 1.3 bar (more than atmospheric pressure). 


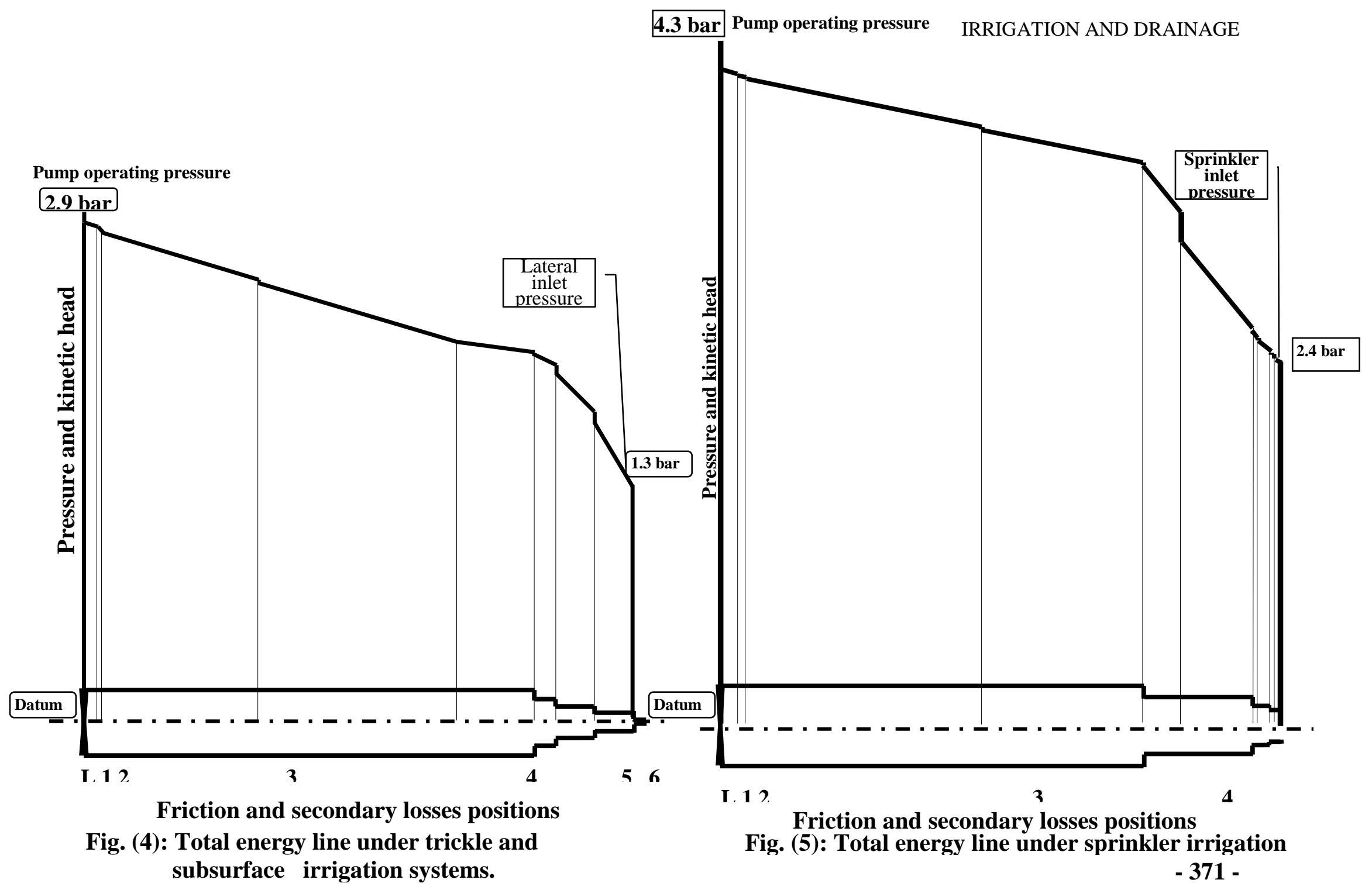


The same analysis also shows that the required pump pressure to operate the sprinkler irrigation system must not be less than 4.3 bar so as to pump water from the sprinklers at pressure of 2.4 bar.

\subsection{The required pump power for operating the used irrigation systems}

Pump must add energy to the water to overcome water power in every irrigation system. The operating pump power under trickle and subsurface irrigation systems was calculated as follows:

$$
\begin{gathered}
H_{m}=H_{m s}+H_{m d} \\
H_{m}=44+29=73 \mathrm{~m} \\
B H P=\frac{W \times Q \times H_{m}}{\eta_{m} \times 75} \\
B H P=\frac{1000 \times 100 \times 73}{0.8 \times 75 \times 3600}=33.8 h p
\end{gathered}
$$

So, required pump power $=1.1 \times \mathrm{BHP}=1.1 \times 33.8=38.2 \mathrm{hp}=27.3 \mathrm{~kW}$ The operating power under sprinkler irrigation system was calculated as follows:

$$
\begin{aligned}
& H_{m}=H_{m s}+H_{m d} \\
& H_{m}=44+43=87 \mathrm{~m} \\
& B H P=\frac{W \times Q \times H_{m}}{\eta_{m} \times 75} \\
& B H P=\frac{1000 \times 100 \times 87}{0.8 \times 75 \times 3600}=40.3 \mathrm{hp}
\end{aligned}
$$

So, required pump power $=1.1 \times \mathrm{BHP}=1.1 \times 40.3=44.3 \mathrm{hp}=32.6 \mathrm{~kW}$ The above mentioned calculations show that a pump with power of not more than $32.6 \mathrm{~kW}$ operate the three used irrigation systems efficiency instead of the already used pump in the experimented area $(44.1 \mathrm{~kW})$. This will be saved power with percentage of $26 \%$.

\subsection{Flow characteristics of emitters, leaky pipes and sprinklers.}

The discharge of water depends on the head pressure. Fig. (6) shows the flow rates of water for irrigation systems under different pressures. The relationship between discharge and operating pressure was natural (the discharge of the irrigation systems increased by increasing the pressure). Relating to trickle irrigation system, increasing the pressure from 0.5 to 2.5 bar, the emitter discharge will be increased by 1.57 to $5.37 \mathrm{l} / \mathrm{h}$. 


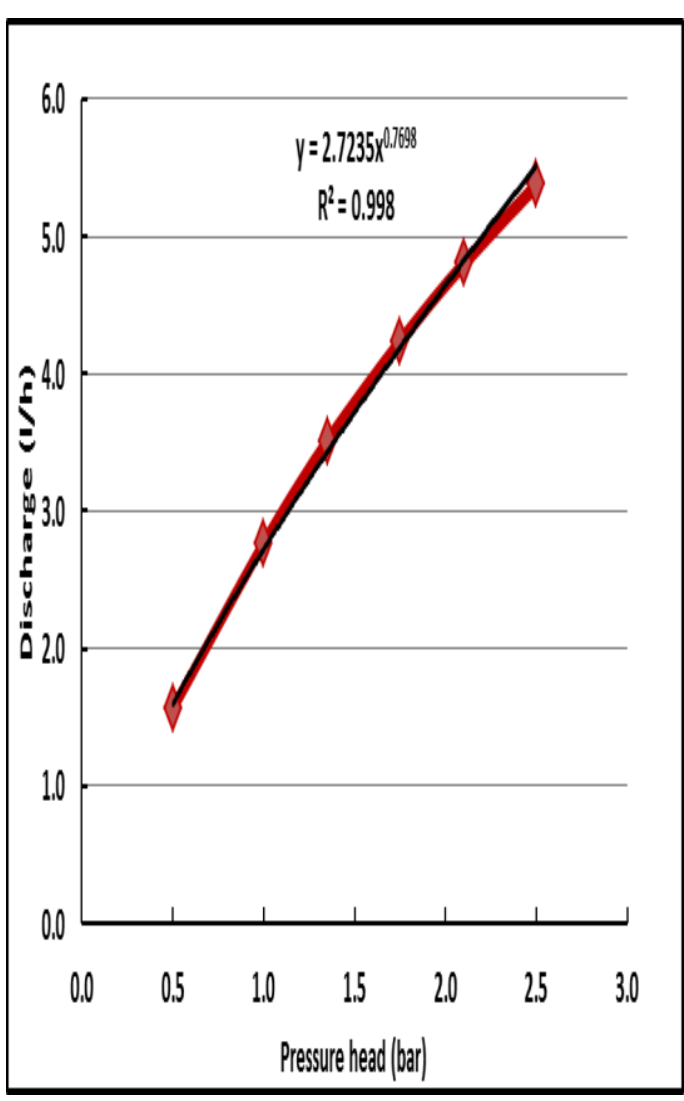

Emitter GR lateral

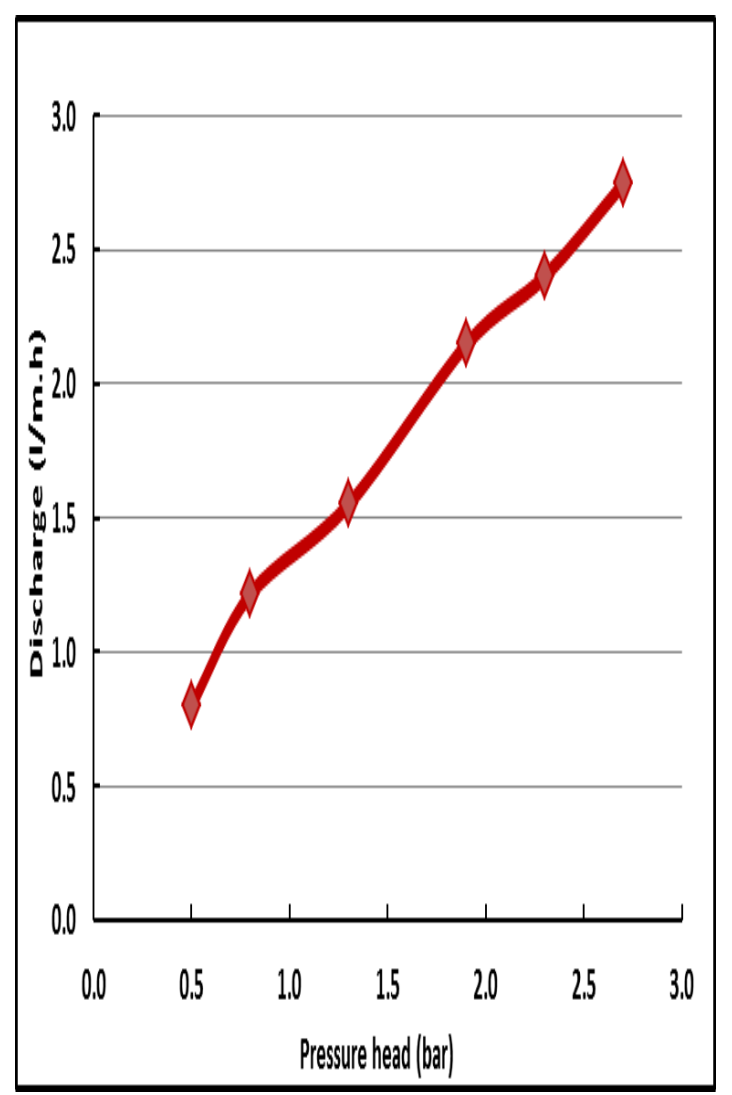

Subsurface leaky pipe

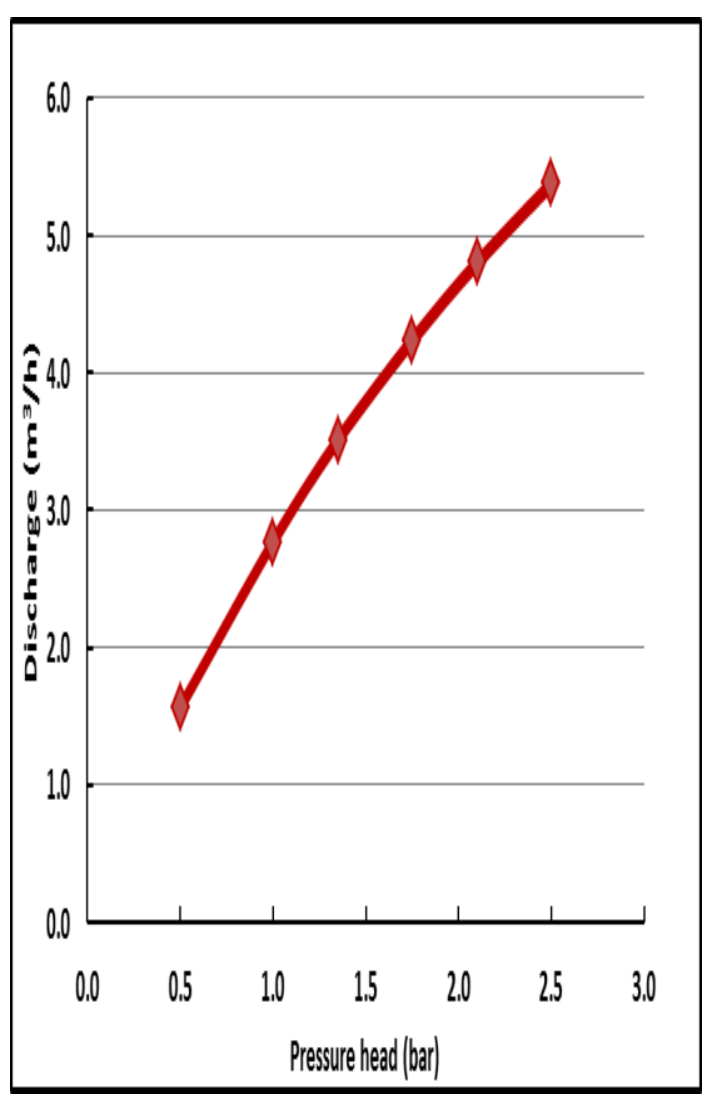

Sprinkler

Fig. (6): The relation between the discharge and pressure head under the different irrigation systems. 
The sensitivity to pressure of an emitter discharge depends mainly on the values of $\mathrm{x}$, which determine how the discharge is sensitive to pressure. The value of $x$ typically falls between 0.1 and 1.0, mainly depending on the manufacture and design of the emitter, i.e. hydraulic characteristics.

The exponent $\mathrm{x}$ of the emitters was equal to 0.77 , meaning that the flow rate in the emitters is between a practically laminar and turbulent. For a fully laminar flow regime, emitters must be very sensitive to pressure changes. Considering subsurface irrigation system, the highest discharge value was $5.74 \mathrm{l} / \mathrm{m}$ under pressure 2.7 bar and the lowest value was 2.8 $1 / \mathrm{m}$ under pressure of $0.8 \mathrm{bar}$. By increasing the pressure from 1.3 to 2.3 bar, the discharge increased from $3.55 \mathrm{l} / \mathrm{h}$ to $4.8 \mathrm{lit} / \mathrm{h}$.

Relating to sprinkler irrigation system Fig. (6) shows that the sprinkler irrigation needs pressure more than trickle and subsurface irrigation systems. The highest discharge value of $2.45 \mathrm{l} / \mathrm{h}$ was achieved with pressure of 5 bar, while the lowest value of $1.45 \mathrm{l} / \mathrm{h}$ was achieved with pressure of 2 bar.

\section{Efficiencies of the used irrigation systems}

\subsection{Application efficiency}

Application efficiency is the key factor in determining the irrigation schedule and the irrigation time. The application efficiency of the irrigation systems is a measure of how well the irrigation water is applied, that is, the percentage of water applied stored in the root zone and available for plant use. The data presented in Fig. (7) shows that the application efficiency of subsurface, trickle and sprinkler irrigations were 97.66, 92.17 and $81.19 \%$ respectively. This value is in agreement with the range recommended by Keller and Blienser (1990) (70 to 88\%) for fixed lateral. The application efficiency for trickle and subsurface irrigations increased by 20.2 and $13.44 \%$ more than sprinkler irrigation.

\subsection{Emission uniformity}

The present data in Fig. (7) shows the emission uniformity values for trickle irrigation systems. The emission uniformity for trickle irrigation was $96.08 \%$. These values are in agreement with the range recommended by Merriam and Keller (1978) (more than 90\%). 


\subsection{Coefficient of uniformity}

A useful term for placing a numerical value on the uniformity of application for agricultural irrigation systems is coefficient of uniformity (CU). Fig. (7) shows the data of coefficient of uniformity under sprinkler irrigation system. The coefficient of uniformity was $95.56 \%$.

\subsection{Flow rate variation}

With regard to the flow rate variation, flow rate variation is used to describe the uniformity of emitter, leaky pipe and sprinkler flow, as caused by the hydraulic design and manufacturing variability. Fig. (7) shows that the flow rate variation for sprinkler irrigation system was $7.65 \%$. The flow rate variation under sprinkler irrigation system increased from 4 and 5 to $7.65 \%$ compared with subsurface and trickle irrigation systems respectively. The lowest value was $4 \%$ achieved with subsurface irrigation system, while the highest value was $7.65 \%$ achieved with sprinkler irrigation system.

\subsection{Irrigation system efficiency}

Data insulted in Fig. (7) shows the irrigation system efficiency under different irrigation systems. The irrigation system efficiencies were 97.66, 92.17 and $81.19 \%$ under subsurface, trickle and sprinkler irrigation systems.

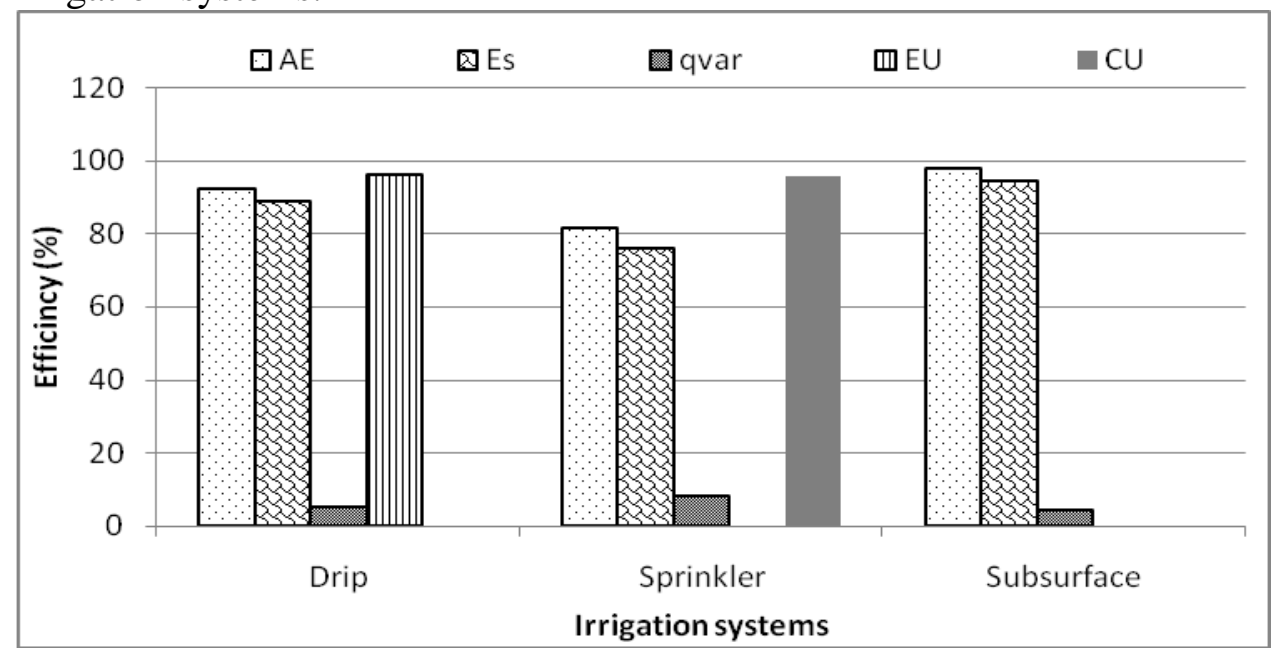

Fig. (7): Application efficiency, emission uniformity, irrigation system efficiency, coefficient of uniformity and flow rate variation of the used irrigation systems. 


\section{CONCLUSION}

- Required pump pressure to operate trickle, subsurface and sprinkler irrigation systems must be not less than 2.9,2.9 and 4.3 bar respectively under conditions of the present study.

- The required pump power to operate trickle, subsurface and sprinkler irrigation systems must be not more than $32.6 \mathrm{~kW}$ instead of the already used pump in the experimented area $(44.1 \mathrm{~kW})$ that will be saved power with percentage of $26 \%$.

- The exponent $x$ value of drippers was 0.77 meaning that the flow rate through emitters is between laminar and turbulent.

- Values of application efficiency and emission uniformity for subsurface irrigation systems were much higher than trickle irrigation.

\section{REFERENCES}

Abdel-Aziz, A. A. (2003). Possibility modern irrigation systems in the old citrus farms and economic return. J. Agric. Mansoura Univ., 28 (7): 5621-5635.

Burt C.M, A. J. Clemmens, T. S. Strelkoff, K. H. Solomon, R. D. Bliesner, L. A. Hardy, T.A. Howell and D.E. Eisenhauer (1997) Irrigation performance measures: Efficiency and uniformity. J. Irr. And Drain. Eng. 123 (6) 423-442.

Christiansen, J. E. (1942) Irrigation by sprinkling. Un. of Calif. Agric. Exp. Sta. Berkely, Bull. 670, 124P.

Dukes M.D., M.B. Haley and S. A. Hanks (2006) Sprinkler irrigation and soil moisture uniformity. Paper presented at the 27th ann. Int. irr. show, San Antonio, TX, USA: 446-460.

Griffiths B. and N. l. Lecler (2001) Irrigation system evaluation. Proc. S. Afr. Sugar Tec. Ass. 75 : 58-67. 
Hazen, A. and G. S. Williams (1920) Hydraulic Tables ( $3^{\text {rd }}$ ed.), N. Y.: John Wiley and Sons.

Keller, J. and D. Karmeli (1975) Trickle irrigation design parameters. Trans. of the ASAE, 17 (4): 678-684.

Keller, J. and R.D. Bliesner, (1990) Sprinkler and Trickle Irrigation. Van Nostrand Reinhold, N. Y.

Merriam, J. L. and J. Keller (1978) Irrigation System Evaluation: A Guide for Management. $3^{\text {rd }}$ ed. Pub. by Ag. and Irr. Eng. Dep., Utah St. Un., Logan, Utah.: 271 p.

Nasab S.B., F. Baradarane-Hezave and M. Behzad (2007) Technical evaluation of sprinkler irrigation systems in Arak. Iran. J. Appl. Sci. 7(21): 3338-3341.

Safi, B., M. R. Neyshabouri and A. H. Nazem (2007) Water application uniformity of subsurface drip irrigation system at various operating pressures and tape lengths. Turk J. of Agric. and Forest. 31: 275-285.

Shawky, M. E., F. A. Gomaa, G. A. Bakeer and A. S. Mostafa (2001) Actual and calculated irrigation water requirement of green bean crop under different irrigation systems in Egypt. Misr J. Agric. Eng., 18 (3): 511-526.

Warren, V. and M. Hammer (1998) Water Supply and Pollution Control, $6^{\text {th }}$. ed. Addison-Wesley. Table 6-1.

Wu, I. P. (1992) Energy gradient line approach for direct calculation in drip irrigation design. Irr. Sc. 13 :21-29.

Wu, I. P. and H. M. Gitilin (1975) Irrigation efficiency of surface, sprinkler and drip irrigation. Reprinted from Proc. $2^{\text {nd }}$. World Con. Int. Water Res. Assoc., New Delhi, 1: 191-199. 


\section{الملخص العربي \\ الخواص الهيدروليه وتقييم أداء نظم الرى الحديث \\ ii محمد محمد مراد حسن _ السادت ابراهيم علي عبد العاله}

تلعب الخو اص الهيدرولية لنظم الرى الحديث دورا رئيسيا فى أداء نظام الرى المستخدم ومدى

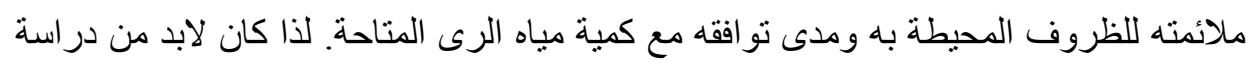
الخو اص الهيدرولية وذلك لتحديد ضغط التشغيل المناسب لكل نظام رى وكفاءة النظام. أجريت هذه الدر اسة بمحطة تجارب الاحتياجات المائية ـ وادي النطرون خلال الموسم الزر اعي

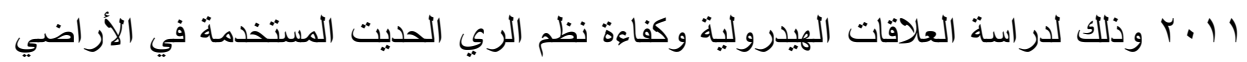
الجديدة تحت الظروف المصرية. وقد تم در اسة العو امل الهيدرولية التالية: ضغط التشغيل المطلوب و الفو اقد الرئسية و الثانوية لكل نظام ـ معامل الانتظامية ـ معدل التصرفـ كفاءة نظام الرى وذلك لنظم الري بالرش - الرى

$$
\text { بالتنقيط ـ الرى تحت السطرى السطى. }
$$

ا ـ أن ضغط التشغيل المطلوب لتشغيل كلَ من نظام الرى بالتنقيط و الري تحت السطحى يجب

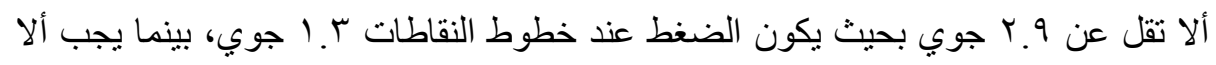
يقل عن ؟.ء جوي بحيث يكون عند الرشاش ع.ب جوي في نظام الرى بالرش. r - أن قدرة المضخة المطلوبة لتشغيل كل نظم الري (بالتنقيط - تحت السطحي - بالرش) هي

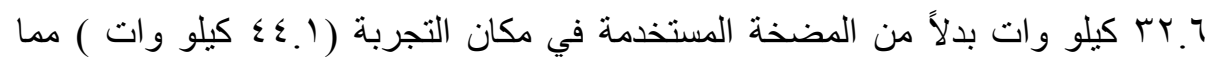

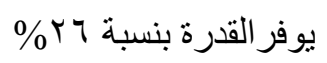

بـ أعطي نظام الرى تحت السطحى و الري بالتنقيط أعلى قيم من حيث كفاءة الاضافة وكفاءة نظام الرى بينما أعطى الرى بالرش أقل القيم، على العكس كان نظام الرى بالرش أعلى فى لقى قياس معامل الاختلاف.

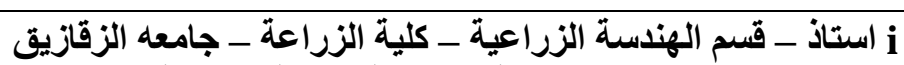

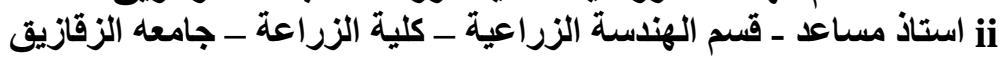

